\title{
Advances in the management of atrial fibrillation in congestive heart failure
}

\author{
Rakesh Gopinathannair and Brian Olshansky*
}

Address: Division of Cardiovascular Medicine, University of Iowa Hospitals and Clinics, Iowa City, IA 52242, USA

*Corresponding author: Brian Olshansky (Brian-Olshansky@uiowa.edu)

FI000 Medicine Reports 2009, I:4 (doi: 10.3410/MI-4)

The electronic version of this article is the complete one and can be found at: http://FI000.com/Reports/Medicine/content/I/4

\begin{abstract}
Atrial fibrillation, a common problem in patients with heart failure, is associated with increased mortality and morbidity. Pharmacological as well as invasive management and the endpoints of such management are complex. Recent randomized trials indicate that a rate-control strategy, along with anticoagulation treatment with warfarin, when appropriate, has a similar outcome in terms of mortality and morbidity as rhythm control, and could, therefore, be considered as the primary management strategy for atrial fibrillation in patients with heart failure.
\end{abstract}

\section{Introduction and context}

Atrial fibrillation and heart failure are emerging and coexisting cardiovascular disease epidemics of the new millennium [1]. Both affect each other and both are associated with substantial mortality and morbidity. Atrial fibrillation, present in $10-40 \%$ of patients with heart failure, is associated with adverse clinical consequences, including excess risk of death, hemodynamic decompensation, exacerbation of heart failure, impaired functional capacity, and risk of stroke [1-7]. The adverse impact of atrial fibrillation in heart failure has been attributed to the presence of irregular and/or excessive ventricular rates, lack of atrial contribution to ventricular filling, and the toxicity of therapies prescribed to control rate, to control rhythm, and to reduce the risk of stroke. In addition to anticoagulation, rate control [drugs or atrioventricular (AV) junctional ablation] is probably the only option for permanent atrial fibrillation, but the optimal strategy for managing paroxysmal and persistent atrial fibrillation in heart failure remains uncertain. Given adverse prognostic implications and postulated hemodynamic consequences, aggressive re-establishment and maintenance of sinus rhythm with antiarrhythmic drugs and/or ablation has been advocated, and frequently attempted, in the hope of achieving better outcomes [8]. On the other hand, interventions to attempt to maintain sinus rhythm may be ineffective, temporary, and potentially toxic.

\section{Recent advances}

Available data show no benefit for a routine rhythmcontrol strategy for management of atrial fibrillation [9-11] but only a small minority of the patients enrolled had systolic dysfunction. A recent prospective, multicenter, randomized clinical trial, termed the Atrial Fibrillation and Congestive Heart Failure (AF-CHF) trial [12], confirms this same finding in the heart failure population. The AF-CHF trial randomized 1,376 patients with paroxysmal or persistent atrial fibrillation, a left ventricular ejection fraction $<35 \%$, and New York Heart Association (NYHA) functional class III or IV heart failure, to a rate-control strategy (using beta-blockers and/or digoxin with AV junctional ablation if drugs were ineffective) or a rhythm-control approach (amiodarone along with electrical cardioversion as needed). The rhythm-control group was associated with a substantial increase in sinus rhythm but no obvious benefit was seen during the $37 \pm 19$-month follow-up. Death from cardiovascular causes, adjusted for baseline differences, was the same in both groups. Secondary outcomes, including death from any cause, stroke, and worsening 
heart failure, were also similar in both groups. Hospitalizations were greater in the rhythm-control group.

It is unclear whether a better therapy to maintain sinus rhythm would have had a better outcome. Given the currently reported success rates of atrial fibrillation ablation, it is unlikely that ablation would be better than the rhythm-control strategy (that is, amiodarone) used in the AF-CHF trial.

In regard to pharmacologic therapy to maintain sinus rhythm, amiodarone appears to be the most potent [13]. Only amiodarone and dofetilide have been shown to have a neutral effect on survival when compared to placebo [4,14-17], but these drugs may have long-term toxicity. Dronedarone, a congener of amiodarone (with its multichannel-blocking abilities, but without its iodine-related moiety), seemed appealing in this regard.

The recently reported Anti-arrhythmic Trial with Dronedarone in Moderate to Severe Congestive Heart Failure Evaluating Morbidity Decrease (ANDROMEDA), compared dronedarone with placebo in atrial fibrillation patients who had heart failure and a left ventricular ejection fraction $<35 \%$ [18]. The study was terminated prematurely after enrolling 627 patients (310 taking dronedarone and 317 taking placebo) over a 7-month period (median follow-up of 2 months) as mortality was significantly increased in the dronedarone arm ( 8.1 versus $3.8 \%$ in the placebo arm). This excess mortality was predominantly due to deaths from worsening heart failure and was greatest in patients with the most severe left ventricular dysfunction. Treatment with dronedarone was the most powerful predictor of death after adjustment for other risk factors. This study dealt a blow at efforts to develop a safe and effective antiarrhythmic drug to use for atrial fibrillation in heart failure.

Although previous studies indicate that atrial fibrillation is independently associated with increased mortality in heart failure, in reality, atrial fibrillation may simply be a marker of poor prognosis, as these heart failure patients may be more ill. Thus, the rhythm by itself may not need treatment except to manage adverse consequences - that is, exacerbation of heart failure and risk of thromboembolism - in selected patients. Available evidence supports this thesis.

Adjunctive therapies, including angiotensin-converting enzyme inhibitors (ACEIs), angiotensin receptor blockers (ARBs), statins, and omega-3 fatty acids, may also help prevent atrial fibrillation in heart failure patients. Modulation of the renin-angiotensin system by ACEIs has been shown to attenuate arrhythmogenic atrial structural remodeling in experimental models of heart failure [19]. A meta-analysis of randomized clinical trials showed that use of both ACEIs and ARBs significantly reduced (relative risk reduction $=44 \%$ ) the incidence of atrial fibrillation in patients with systolic heart failure [20]. Both statins and omega-3 fatty acids have been thought to have favorable effects on atrial structural remodeling in heart failure $[21,22]$, but the exact mechanisms as well as the magnitude of their beneficial effects remain unclear.

\section{Implications for clinical practice}

It is time to rethink the widely held belief that restoration and maintenance of sinus rhythm using antiarrhythmics and serial electrical cardioversions benefits patients with systolic dysfunction and heart failure. A strategy aimed at sinus rhythm does not improve cardiovascular and allcause mortality, risk of stroke, and worsening of heart failure [12]. Instead, it can result in repeated cardioversions, hospitalization from drug-related side effects, and even increased mortality, as shown with the use of dronedarone [18].

Whether invasive attempts at rhythm control, such as by ablation, will improve outcomes, remains to be seen. At present, rate control with appropriate anticoagulation should be considered as the primary strategy to manage atrial fibrillation in patients with heart failure. Betablockers with or without digoxin should be first-line ratecontrol agents but multiple drug combinations and even AV junctional ablation may be needed [23]. In regard to anticoagulation, no substitute exists for warfarin, although direct thrombin inhibitors are being tested [24]. Rhythm control should only be pursued in those highly symptomatic heart failure patients who have rapid uncontrolled atrial fibrillation that fails to respond to standard rate-control therapy and for selected patients who are shown to have worsening heart failure symptoms and/or poor quality of life attributable to atrial fibrillation, despite adequate rate control.

\section{Abbreviations}

ACEI, angiotensin-converting enzyme inhibitor; ARB, angiotensin receptor blocker; $\mathrm{AV}$, atrioventricular.

\section{Competing interests}

The authors declare that they have no competing interests.

\section{References}

I. Braunwald E: Shattuck lecture - cardiovascular medicine at the turn of the millennium: Triumphs, concerns, and opportunities. N Engl J Med 1997, 337:1360-9 
2. Dries DL, Exner DV, Gersh BJ, Domanski MJ, Waclawiw MA, Stevenson LW: Atrial fibrillation is associated with an increased risk for mortality and heart failure progression in patients with asymptomatic and symptomatic left ventricular systolic dysfunction: A retrospective analysis of the SOLVD trials. Studies of Left Ventricular Dysfunction. J Am Coll Cardiol 1998, 32:695-703

3. Middlekauff HR, Stevenson WG, Stevenson LW: Prognostic significance of atrial fibrillation in advanced heart failure. A study of 390 patients. Circulation I991, 84:40-8

4. Deedwania PC, Singh BN, Ellenbogen K, Fisher S, Fletcher R, Singh SN: Spontaneous conversion and maintenance of sinus rhythm by amiodarone in patients with heart failure and atrial fibrillation: Observations from the veterans affairs congestive heart failure survival trial of antiarrhythmic therapy (CHF-STAT). The Department of Veterans Affairs CHF-STAT investigators. Circulation 1998, 98:2574-9

5. Olsson LG, Swedberg K, Ducharme A, Granger CB, Michelson EL, McMurray J], Puu M, Yusuf S, Pfeffer MA; CHARM Investigators Atrial fibrillation and risk of clinical events in chronic heart failure with and without left ventricular systolic dysfunction: Results from the candesartan in heart failure-assessment of reduction in mortality and morbidity (CHARM) program. J Am Coll Cardiol 2006, 47:1997-2004

6. Rationale and design of a study assessing treatment strategies of atrial fibrillation in patients with heart failure (AFCHF) trial. Am Heart J 2002, I44:597-607

7. Effects of enalapril on mortality in severe congestive heart failure. Results of the Cooperative North Scandinavian Enalapril Survival Study (CONSENSUS). The CONSENSUS trial study group. $N$ Engl J Med I987, 3 I6:1429-35

8. Maisel $\mathrm{WH}$, Stevenson LW: Atrial fibrillation in heart failure: Epidemiology, pathophysiology, and rationale for therapy. Am I Cardiol 2003, 9 I:2D-8D

9. Opolski G, Torbicki A, Kosior DA, Szulc M, Wozakowska-Kaplon B, Kolodziej P, Achremczyk P; Investigators of the Polish How to Treat Chronic Atrial Fibrillation Study: Rate control vs rhythm control in patients with nonvalvular persistent atrial fibrillation: The results of the Polish How To Treat Chronic Atrial Fibrillation (HOT CAFE) study Chest 2004, I 26:476-86

10. Wyse DG, Waldo AL, DiMarco JP, Domanski MJ, Rosenberg Y, Schron EB, Kellen JC, Greene HL, Mickel MC, Dalquist JE, Corley SD; Atrial Fibrillation Follow-up Investigation of Rhythm Management (AFFIRM) Investigators: A comparison of rate control and rhythm control in patients with atrial fibrillation. $N$ Engl J Med 2002, 347:1825-33

II. Van Gelder IC, Hagens VE, Bosker HA, Kingma JH, Kamp O, Kingma T, Said SA, Darmanata JI, Timmermans AJ, Tijssen JG, Crijns HJ; Rate Control versus Electrical Cardioversion for Persistent Atrial Fibrillation Study Group. A comparison of rate control and rhythm control in patients with recurrent persistent atrial fibrillation. $N$ Engl J Med 2008, 347: $1834-40$

12. Roy D, Talajic M, Nattel S, Wyse DG, Dorian P, Lee KL, Bourassa MG, Arnold JM, Buxton AE, Camm AJ, Connolly SJ, Dubuc M, Ducharme A, Guerra PG, Hohnloser SH, Lambert J, Le Heuzey JY, O'Hara G, Pedersen OD, Rouleau IL, Singh BN, Stevenson LW, Stevenson WG, Thibault B, Waldo AL; Atrial Fibrillation and Congestive Heart Failure Investigators. Rhythm control versus rate control for atrial fibrillation and heart failure. N Engl J Med 2002, 358:2667-77

Changes Clinical Practice

FI000 Factor 9.8 Exceptional

Evaluated by Brian Olshansky with Chirag Sandesara 15 Jul 2008, Wilbert

Aronow 30 Jul 2008, Hector Ventura with Anil Verma II Aug 2008
13. Roy D, Talajic M, Dorian P, Connolly S, Eisenberg MJ, Green M, Kus T, Lambert J, Dubuc M, Gagné P, Nattel S, Thibault B: Amiodarone to prevent recurrence of atrial fibrillation. canadian trial of atrial fibrillation investigators. N Engl J Med 2000, 342:9|3-20

14. Torp-Pedersen C, Møller M, Bloch-Thomsen PE, Køber L, Sandøe E, Egstrup K, Agner E, Carlsen J, Videbaek J, Marchant B, Camm AJ: Dofetilide in patients with congestive heart failure and left ventricular dysfunction. Danish Investigations of Arrhythmia and Mortality on Dofetilide Study Group. N Engl J Med 1999, 341:857-65

15. Bardy GH, Lee KL, Mark DB, Poole JE, Packer DL, Boineau R, Domanski M, Troutman C, Anderson J, Johnson G, McNulty SE, Clapp-Channing N, Davidson-Ray LD, Fraulo ES, Fishbein DP, Lucer RM, Ip JH; Sudden Cardiac Death in Heart Failure Trial (SCD-HeFT) Investigators: Amiodarone or an implantable cardioverterdefibrillator for congestive heart failure. N Engl J Med 2005, 352:225-37

16. Cairns JA, Connolly SJ, Roberts R, Gent M: Randomised trial of outcome after myocardial infarction in patients with frequent or repetitive ventricular premature depolarisations: CAMIAT. Canadian Amiodarone Myocardial Infarction Arrhythmia Trial Investigators. Lancet 1997, 349:675-82

17. Julian DG, Camm AJ, Frangin G, Janse MJ, Munoz A, Schwartz PJ, Simon P: Randomised trial of effect of amiodarone on mortality in patients with left-ventricular dysfunction after recent myocardial infarction: EMIAT. European Myocardial Infarct Amiodarone Trial Investigators. Lancet 1997, 349:66774

18. Køber L, Torp-Pedersen C, McMurray JJ, Gøtzsche O, Lévy S, Crijns $\mathrm{H}$, Amlie J, Carlsen J: Increased mortality after dronedarone therapy for severe heart failure. N Engl J Med 2008, 358:2678-87

FI000 Factor 3.0 Recommended

Evaluated by Brian Olshansky with Rakesh Gopinathannair 17 Jul 2008

19. Li D, Shinagawa K, Pang L, Leung TK, Cardin S, Wang Z, Nattel S: Effects of angiotensin-converting enzyme inhibition on the development of the atrial fibrillation substrate in dogs with ventricular tachypacing-induced congestive heart failure. Circulation 200I, 104:2608-14

20. Healey JS, Baranchuk A, Crystal E, Morillo CA, Garfinkle M, Yusuf S, Connolly S): Prevention of atrial fibrillation with angiotensinconverting enzyme inhibitors and angiotensin receptor blockers: A meta-analysis. J Am Coll Cardiol 2005, 45:1832-9

21. Liu T, Li G, Korantzopoulos P, Goudevenos JA: Letter to the Editor. Statins and prevention of atrial fibrillation in patients with heart failure. Int J Cardiol 2008, Jul 12 [Epub ahead of print]

22. Sakabe M, Shiroshita-Takeshita A, Maguy A, Dumesnil C, Nigam A, Leung TK, Nattel S: Omega-3 polyunsaturated fatty acids prevent atrial fibrillation associated with heart failure but not atrial tachycardia remodeling. Circulation 2007, I 16:2101-9

23. Olshansky B, Rosenfeld LE, Warner AL, Solomon AJ, O'Neill G, Sharma A, Platia E, Feld GK, Akiyama T, Brodsky MA, Greene HL: The atrial fibrillation follow-up investigation of rhythm management (AFFIRM) study: approaches to control rate in atrial fibrillation. J Am Coll Cardiol 2004, 43:I20I-8

24. Ezekowitz MD, Reilly PA, Nehmiz G, Simmers TA, Nagarakanti R, Parcham-Azad K, Pedersen KE, Lionetti DA, Stangier J, Wallentin L: Dabigatran with or without concomitant aspirin compared with warfarin alone in patients with nonvalvular atrial fibrillation (PETRO study). Am J Cardiol 2007, 100:14|9-26 